\title{
Antineoplastic Enzyme Inhibitor
}

National Cancer Institute

\section{Source}

National Cancer Institute. Antineoplastic Enzyme Inhibitor. NCI Thesaurus. Code C129825.

Any agent that specifically inhibits a particular enzyme that is overexpressed and/or mutated in cancer cell pathways. Antineoplastic enzyme inhibitors specifically target tumor cells by targeting enzymes that are not normally expressed or are minimally expressed in normal, healthy tissues. 